\title{
The Trouble with Teenagers and American Child Pornography Law
}

\author{
Timothy S. McNamara \\ China University of Political Science and Law (CUPL), Beijing, China \\ Email: mcnamara.ts@gmail.com
}

How to cite this paper: McNamara, T. S. (2022). The Trouble with Teenagers and American Child Pornography Law. Beijing Law Review, 13, 23-46.

https://doi.org/10.4236/blr.2022.131002

Received: January 17, 2022

Accepted: February 25, 2022

Published: February 28, 2022

Copyright $\odot 2022$ by author(s) and Scientific Research Publishing Inc. This work is licensed under the Creative Commons Attribution-NonCommercial International License (CC BY-NC 4.0). http://creativecommons.org/licenses/by-nc/4.0/

\begin{abstract}
This paper is concerned with the contradictions which have emerged in American law and policy as millions of young people, perhaps even the majority, have now become unrecognized sex criminals. The historical reality is that as the Internet became popular in the 1990s, fear grew over the mix of anonymity, Internet predators and the naivety of child web users. In response, child pornography laws were strengthened as the "evil" to be criminalized became twofold: 1 ) the producers (via the production process and sale of such images) as well as 2) the images themselves (via their possessor). It was only a decade or so later that the growth of Internet-accessible phones with camera technology became widely available to teenagers. This historical reality, which in many ways is simply an accident, accounts for the strict child pornography laws that, in hindsight, have been very poorly written. The intended beneficiaries of the laws are often now committing crimes, reliant upon the goodwill and common sense of prosecutors to not bring charges against them. However, in general, many of these children will become de facto criminals living in a weaker and weaker legal position over time, at least for as long as they continue to possess those images. For example, public opinion may tolerate an 18-year-old man with a memorial nude photo of his former girlfriend, taken when they were both 16. Public opinion, and most likely the law as well, will grow less tolerant as he ages and in particular if he does not marry that girl. The law in practice often does not live up to the law in theory. The paper has three substantive sections: it summarizes the historical development of the law, explores the legal issues surrounding teens and their phones, and hints at potential solutions to the current dilemmas.
\end{abstract}

\section{Keywords}

Revenge Pornography, Sexting, American Child Pornography, Decriminalization, Selfies 


\section{Introduction}

Abuse of children for the sexual pleasure of adults is a reviled and nearly unfathomable act which brings about almost universal moral condemnation, disgust or revulsion. Both international instruments ${ }^{1}$ and municipal laws have been implemented to prevent such abuse from occurring and anecdotal evidence suggests that attitudes towards this issue in the third world have been slowly changing as well. Thus, the risk of such abuse occurring under for-profit conditions appears to be receding. However, public discussions around the child protection laws often fail to distinguish between pre-pubescent children (e.g. six-year-olds) and older children (e.g. sixteen-year-olds), or the coerced and the consensual.

This problem has become particularly evident in regards to child pornography law and the failure of the law to account for child autonomy and older children's use of their camera-equipped smart phones when communicating with each other. Simply put, the law has not kept up with technological reality and does not properly account for human nature (i.e. the behavior of young people). Worse still, the intellectual confusion and false media narratives continue to stifle discussion. In fact, if the child pornography laws were applied literally, millions of American young people, perhaps as many as half of 15 to 30 -year-olds, would likely qualify as child sex offenders (i.e. child pornographers).

The purpose of this Note is threefold: 1) to trace how the law developed (see Section 2), 2) to explore how the law is being applied, with emphasis on teenagers and young adults (see Section 3), and 3) to consider recommendations for reforming the law (see Section 4).

\section{Historical Overview}

The evolution of America's child pornography laws is best understood as having developed under a three-stage process. First, under the US Constitution, great deference is given to the right to free speech. Almost from the founding of the Republic, however, the American people's disgust with lewd and obscene material ${ }^{2}$ became evident. Notwithstanding the First Amendment, the judiciary was forced to intervene and since 1815 the Court has consistently held that obscenity is outside the First Amendment's protection guarantees (Pollard, 1990: p. 143).

Second, in the post WWII era, pornography gradually came to be recognized as a legitimate form of art, as courts sought to distinguish plain vanilla pornography from the more extreme forms which continued to be labelled "obscene". Anti-obscenity and anti-pornography rulings go back to the eighteenth century. ${ }^{3}$ However, according to Florence Rush, enforcement was generally done for po-

${ }^{1}$ See, for example, Art 34 of the Convention on the Rights of the Child, Arts 8 and 10 of the Optional Protocol on the Sale of children, Child Prostitution and Child Pornography or Art 9 of the Council of Europe's Convention on Cybercrime.

2"Obscenity" is defined in the Merriam-Webster dictionary as "the quality of being obscene". "Obscene", in turn, is primarily defined as "disgusting to the senses" and "abhorrent to morality or virtue". See https://www.merriam-webster.com/dictionary/obscene. (Accessed January 15, 2022.) Note as well that obscenity is also a legal term of art. Unfortunately, however, some writers seem to prevaricate and use both legal and plain meanings interchangeably. 
litical rather than moral reasons. ${ }^{4}$ It was not until the early twentieth century that obscenity laws were seriously executed. ${ }^{5}$ Effectively, a degree of intellectual clarity was achieved when it was found that not all pornography was "extreme", thus granting it legal legitimacy.

Third, a distinction eventually emerged between child pornography and obscenity. Formerly, all child pornography would likely have been deemed obscene. Yet, an "art form" emerged in the 1970s under Blue Lagoon-type films, and even more explicit ones, which many liberal intellectuals failed to oppose. ${ }^{6}$

In reading older academic papers covering child pornography, a casual reader might initially be confused as it will be claimed by some writers that child pornography was illegal, or at least unlawful, throughout American history. However, other scholars will claim that this strange phenomenon was not illegal, and therefore needed new legislation and a special carve-out from the First Amendment's free speech protections.

In truth, both claims have a basis in fact: child pornography as popularly imagined (e.g. abuse of a six-year-old on film) would be repulsive to almost all communities in the US and, thus, would have always been covered by existing obscenity law. However, two problems emerged over time.

The first problem was technical as film producers, perhaps in an attempt to be avant-garde or risqué, in an increasingly secular society began to use younger actresses and "push the boundaries" of acceptable portrayals. Originally, television and silent films had been adult-dominated with rigid roles assigned to fathers, mothers and children. However, in reality, teenagers may be adults (e.g. eighteen or nineteen-year-olds) or simply deemed adults for some purposes (e.g. sixteen is the minimum age for sexual consent in many jurisdictions and even younger thresholds may apply for the purposes of child labor or for trial as an adult in an American criminal court). For whatever the exact reason-and it may have been simply demographic dominance-the increasing importance of the Baby Boom generation seems to partly account for the new and expanded role of youth culture in 1960s and 1970s television.

Secondly, it must be recognized that the law both fosters social consensus and is itself shaped by social consensus. This dynamic is complex and largely outside the purview of our current discussion. It is clear, however, that the larger trend of American history, particularly in the twentieth century, has been towards ever greater social and legal tolerance of alternative sexual lifestyles. What began with tolerance towards the single lifestyle may have become glorification of the single

3"Panel Discussion: Effects of Violent Pornography," New York University Review of Law and Social Change 8, no.2 (1978-1979): 225-246 at 228.

${ }^{4}$ Ibid.

${ }^{5}$ Ibid. (Opinion of Florence Rush). Some, but not all, sexually violent material is "obscene".

${ }^{6}$ It was around this time that Ruth Ginsberg famously failed to condemn child sexual abuse, and appeared to recommend lowering the age of statutory rape for girls to 12 . However, in fairness, her actual comment had been somewhat more ambiguous as she simply recommended eliminating gender differences with respect to the age of statutory rape: this could be interpreted as lowering it for girls or raising it for boys. Texe Marrs, Big Sister is Watching You 129 (1993), citing R.E. McMaster, The Reaper, May 19, 1993 at 14. 
lifestyle and this attitudinal shift regarding pre-marital sexual relations appears to have often extended to pornography, infidelity and homosexuality. Although conservatives may have disliked this trend, it was only really when pornographers began to turn their attention to children that many feminist academics also became concerned.

The release of films such as Blue Lagoon effectively pushed the boundaries, either through the portrayal of adults in the roles of children or children in the traditional roles of adults. The failure of obscenity law to prevent the release of this or even more explicit films reflects a certain breakdown in the prevailing social order.

As the obscenity test relies on community values to be enforced, the law sets a fairly high threshold. Generally, all twelve jurors must agree. In times of turbulence (e.g. the 1970s or the 2020s), values will be in flux. Formerly acceptable or even mainstream statements and views might invite hostility or, in the current context, "cancelling". Within such a context, both psychology and the law will become unpredictable. For example, if psychiatrists re-label formerly deemed mental illnesses as no longer mental illnesses under the new psychiatry, then criminal convictions may also become more difficult as jurors can confuse the moral good with the social good, and vice versa. ${ }^{\text {? }}$

\section{Distinguishing Obscenity from Pornography}

Although pornography is now associated with visual depictions, the word itself derives from the Greek "pornographos" meaning "writing about prostitutes". Early case law reflects this as many of the cases involving the obscenity test also concerned the written word (novels) sold in bookstores. For example, one of the more pivotal cases, Butler v. Michigan, ${ }^{8}$ centered on whether a few isolated yet steamy passages in the novel The Devil Rides Outside were gratuitous (Bradley, 2018: p. 462). In what amounted to an "expert witness contest" between religious leaders and a group of professors, the Supreme Court sided with the professors:

${ }^{7}$ It should be recognized at the outset that the term "pedophile" has been defined as "an adult person who is sexually attracted to an immature child of either sex". See Fraser, Child Pornography, New statesman, Feb 17, 1978 at 213. Note: Americans tend to use language more precisely here, distinguishing between pedophiles and child molesters. The former, as a contraction of Greek words representing "child" and "lover of" refers to physical attraction towards children, regardless of whether this is acted upon. In contrast, "child molester" refers to a person who commits the crime of sexual assault on a child, regardless of attraction. The recent British tendency to refer to both categories simply as "pedophiles" is unfortunate and at times confusing. See also Kenneth V. Lanning, Child Molesters: A Behavioral Analysis for Professionals Investigating the Sexual Exploitation of Children, ( $5^{\text {th }}$ ed 2010) at 19-20, available at http://commcns.org/18aSgy0 explaining that the more precise terms are "hebephilia" for attraction towards eleven to fourteen-year-olds and "ephebophilia" for attraction towards fifteen to nineteen-year-olds. (Accessed January 15, 2022.) The professional opinion of psychiatrists may be surprisingly divergent from popular opinion on this issue. See Allen Frances and Micheal B First, "Hebephilia is Not a Mental Disorder in DSM-IV-TR and Should Not Become One in DSM-5" (2011) 39 (1) Journal of the American Academy of Psychiatry and the Law 78. Note: DSM-IV-TR refers to the American Psychiatric Association, Diagnostic and Statistical Manual of Mental Disorders 532 ( $4^{\text {th }}$ ed. 1994), a sort of "Bible" for psychiatrists. As an example of the complex relationship between professional psychiatry and popular culture, in 1973 the APA removed homosexuality as a mental illness from the DSM III.

${ }^{8} 352$ U.S. 380 (1957). 
curtailing adult access to the novel effectively would have meant only adults would be able to read books fit for children. ${ }^{9}$

In Chaplinsky v. New Hampshire $e^{10}$ the Court stated that obscenity played "no essential part" in the marketplace of ideas and was of only "slight" social value. This was followed by Roth $v$. United States ${ }^{11}$, in which the Court stated that obscenity was without "redeeming social importance" and thus outside the ambit of First Amendment protection. ${ }^{12}$ Later, in the Memoirs ${ }^{13}$ case, the Court's stance was further modified/clarified: sexually explicit material was not obscene unless "utterly without redeeming social value".

It appears that the US Supreme Court opened the door towards both greater tolerance of obscenity and greater recognition of the right to privacy in 1969 with its famous Stanley v. Georgia ${ }^{14}$ decision, where it overturned the conviction of a man who knowingly possessed obscene film materials at his home. The Court stated that:

If the First Amendment means anything, it means that the State has no business telling a man, sitting alone in his house, what books he may read or what films he may watch. Our whole constitutional heritage rebels at the thought of giving the government the power to control men's minds. ${ }^{15}$

The 1970s marked an important turning point in the American law's approach to obscenity. In the face of free speech aspects of the First Amendment it often became unclear how moral arguments could be used to advance restrictions on speech such as pornography in general and obscenity in particular. In 1973 The Supreme Court abandoned the national obscenity standard and allowed States to set their own. ${ }^{16}$ To wit, in Miller v. California ${ }^{17}$ the Court modified the earlier $R o t h{ }^{18}$ test and replaced it with the current three-pronged test for determining if material was obscene:

1) whether "the average person, applying contemporary community standards" would find that the work, taken as a whole, appeals to the prurient interest,

2) whether the work depicts or describes, in a patently offensive way, sexual conduct specifically defined by the applicable state law, and

3) whether the work, taken as a whole, lacks serious literary, artistic, political, or scientific value. ${ }^{19}$

However, the Court never definitively defined "prurient interest" and thus confusion has never fully abated over the distinction between expressions of a

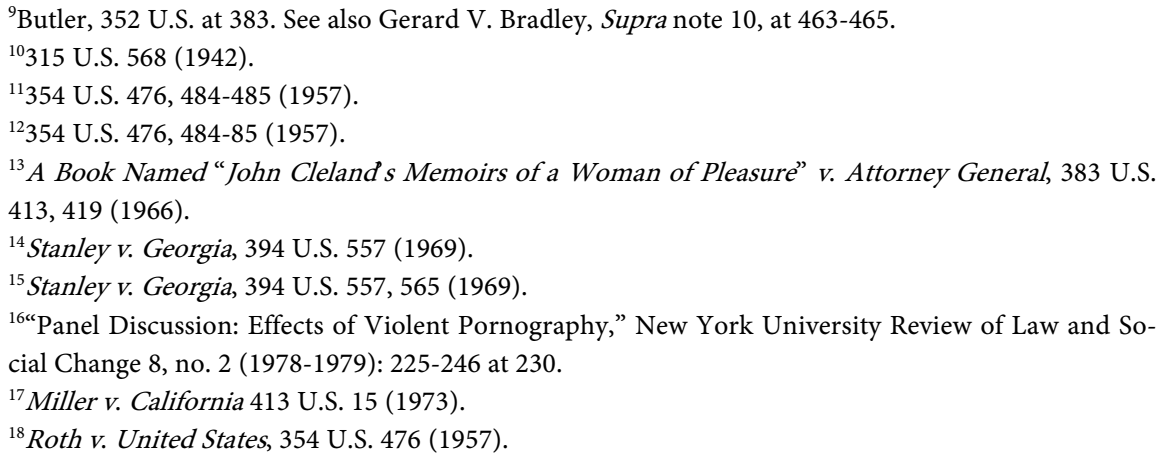


normal interest in sex (which are protected by the First Amendment) and expressions of a morbid or shameful interest (which are not protected) (Ortiz, 2001: p. 952). Nonetheless, the Court described the prurient interest as a "shameful or morbid interest in sex, as contrasted with a normal or healthy interest" (Pollard, 1990: p. 145).

\subsection{Distinguishing Child Pornography from Obscenity}

As States began to outlaw child pornography specifically, rather than simply assuming it would continue to be subsumed within the broader obscenity category, some curious patterns developed. Generally, by modern standards, the States' initial laws were quite timid. Kentucky, New York and Wisconsin, for example, barred child nudity only insofar as it was "obscene" or "lewd". Other States tried to ban all child nudity yet the Supreme Court stated in Erznoznik v City of Jacksonville ${ }^{20}$ that a blanket prohibition on all nudity was unconstitutional (Payton, 1978-1979: p. 527). Still other States, such as Texas and Louisiana, did not define "sexual conduct" and, as such, were criticized for excessive vagueness (Payton, 1978-1979: p. 528). For example, it was suggested even kissing might be "sexual conduct" (Payton, 1978-1979: p. 528). Also, the definition of "minor" varied with some States specifying "under 16" and others opting for "18 years or less" (Payton, 1978-1979: p. 530). As regards the so-called "artistic exception", the legislation generally focused on criminalizing specific acts rather than viewing the works as a whole (Payton, 1978-1979: p. 531).

The early, lower level court challenges to child pornography-type legislation were unfavorable to the legislation (Payton, 1978-1979: p. 531). St Martin's Press v. Carey $^{11}$ concerned a book of pictures, Show Me!, of a young boy and girl exploring each other's bodies, and intended to assist parents in explaining to their children about sex (Payton, 1978-1979: p. 532). The Court found the book was not obscene under the Miller test as it did not lack scientific value (Payton, 1978-1979: p. 533). Furthermore, the Court found that although New York had a legitimate interest in protecting children from exploitation, the statute's construction was overly broad in terms of its goal (Payton, 1978-1979: p. 533).

The case of Graham v. HilP ${ }^{2}$ concerned a provision in the Texas penal code which made it a criminal offence to sell, distribute or exhibit material showing a person under 17 years of age observing or engaging in sexual conduct (Payton, 1978-1979: p. 534). The statute was held to be overbroad and it might be argued that the wording was also quite curious: no depiction of sexual activity was even required, since a film might "show" a minor observing the activity without the film actually depicting it directly (Payton, 1978-1979: p. 535).

Of course, most of what the public would consider as child pornography was already covered by obscenity law in 1978 (Payton, 1978-1979: p. 541). In the US, most of the child victims who partook in such films were runaways, so the prob-

\footnotetext{
${ }^{19}$ Miller v. California 413 U.S. 15 at 39 (1973).

${ }^{20} 422$ U.S. 205 (1975).

${ }^{21} 440$ F. Supp. 1196 (S.D.N.Y. 1977).

${ }^{22} 444$ F. Supp. 584 (W.D. Tex. 1978).
} 
lem of how to protect runaways was also seen as integral to this as a social issue (Payton, 1978-1979: p. 542). Academic opinion in the 1970s was generally more pro-free speech than today, both in relation to sexual speech and hate speech. Jennifer Payton, for example, appears to have argued against new child pornography laws, perceiving the existing obscenity provisions as sufficient (Payton, 1978-1979: p. 543).

In terms of legislation, in 1977 there were five Federal laws prohibiting the distribution of obscene materials in the US: mailing, importing, broadcasting, transportation and use of common carriers (Payton, 1978-1979: p. 511). As well, there were periphery laws of specified relevance such as the Federal Anti-Pandering Act (to stop unsolicited advertisements) and the Mann Act (prohibiting the interstate transportation of female minors if done for the purpose of prostitution) (Payton, 1978-1979: p. 511).

Following the Ferber decision (holding that sexual images of minors were not protected speech), the Child Protection Act of 1984 removed the obscenity requirement from American child pornography laws (Clough, 2012: p. 222). One of the reasons for the US Congress changing the definition of a child (for child pornography purposes) from below 16 to below 18 years of age was to facilitate prosecutions (Clough, 2012: p. 225).

Although it might be argued that divorcing the age of consent from the age at which sexual photos may be taken lacks a rational basis, US courts have upheld these laws. In People $v$ Campbell, ${ }^{23}$ a husband was found guilty for the possession of a photo of his 18-year old wife engaged in sexual acts with a 15-year old female. Although the activities between the two females had been legal under Colorado law, the taking of the photo was not. The Court concluded that it was open to the legislature to conclude that taking such photos was more harmful than the underlying act.

\subsection{The 1970 and 1986 Presidential Commissions}

The 1970 National Committee on Obscenity and Pornography published its findings, which included a view that not only was pornography helpful to discussions of sexuality between parents and children but also that pedophilia was so far outside mainstream interest as to be almost non-existent. ${ }^{24}$ The 1970 Commission also found pornography to be essentially harmless and perhaps even slightly beneficial in terms of sexuality (Mather, 1992: p. 476). In contrast, the better known and more controversial 1986 Commission established by Attorney General Edwin Meese found exposure to violent pornography led to increased aggression and sexual violence (Mather, 1992: p. 477).

The 1970 Commission had taken a starkly different view of pornography from the Meese Commission. The 1970 Commission found:

1) pornography is not harmful

${ }^{23} 94$ P 3d 1186 (Colo Ct App, 2004).

24"Panel Discussion: Effects of Violent Pornography," New York University Review of Law and Social Change 8, no. 2 (1978-1979): 225-246 at 229. 
2) it is even educational

3 ) it encourages frank discussions between parents and children

4) it releases inhibitions

5) it is not a causal factor in crime

6) it is not a matter of public concern

7) pedophilia is outside the interests of pornography

8) the taboo against pedophilia continues and

9) the use of pre-pubescent children is virtually non-existent. ${ }^{25}$

Although there were counter-examples cited by feminists, it is unclear if these were rare counter-examples or somewhat mainstream. ${ }^{26}$ Some members of the 1970 Commission produced studies showing pornography was physically dangerous, encouraged child molestation and rape, and damaged the public and self-image of children. ${ }^{27}$

In 1973 the Supreme Court abandoned the national definition of obscenity and allowed individual States to set their own guidelines. ${ }^{28}$ The 1970 Commission's constitutional lawyer, Paul Bender, argued that "obscenity" had become protected speech under the First Amendment as a distinction between the transmission of ideas versus the transmission of pure entertainment was too thin a line to be drawn or maintained (Bradley, 2018: pp. 473-474). However, President Nixon rejected the Commission's findings as “morally bankrupt” (Bradley, 2018: p. 474).

Looking at the Supreme Court's judgments from 1957 until the present, we find no moral sanctioning of obscenity (Bradley, 2018: p. 477). Instead, the Court has been concerned with indecency, offence and harmful secondary effects (Bradley, 2018: p. 477).

The 1986 Commission recognized that the "taboo" surrounding child pornography had been broken and so they recommended measures to prosecute those who made and accessed it (Bradley, 2018: pp. 478-479). Not only had the popular mores changed but so had pornography itself (Bradley, 2018: p. 479). Some even asserted that pornography had been a factor in causing mores to change (Bradley, 2018: p. 479). And by the time of the Meese Report, violent or degrading pornography had become the most prevalent form (Bradley, 2018: pp. 479-480).

\subsection{Evolution of US Child Pornography Law}

Child pornography does not require nudity. Contrary, to popular belief, child pornography is not synonymous with sex involving a child or child nudity. Under the formula laid down by the US Court of Appeals for the Third Circuit in United States $v$. Knox, ${ }^{29}$ lascivious exhibition of the genitals or pubic area may constitute child pornography even if those body areas were covered by clothing 25"Panel Discussion: Effects of Violent Pornography," New York University Review of Law and Social Change 8, no.2 (1978-1979): 225-246 at 229.

${ }^{26} \mathrm{Ibid}$. Florence Rush cites a number of magazines and films such as Little Girls which featured pictures of ten to twelve-year-old children having intercourse with adult males.

27"Panel Discussion: Effects of Violent Pornography," New York University Review of Law and Social Change 8, no.2 (1978-1979): 225-246 at 229.

${ }^{28}$ Ibid., at 230 . 
and not discernable. ${ }^{30}$ In Knox, all the young children were clothed but, because of the photographer's zooming in on their private parts for an extended period of time, the video was deemed to be child pornography. ${ }^{31}$

As outlined above, there is considerable overlap involving child pornography and obscenity: some child pornography would be recognized as obscene, but not all, while some obscene pornography involves children, but not all.

In the late 1980s and early 1990s there was considerable uncertainty over whether child pornography was actually increasing or if this was simply a fear-driven myth. ${ }^{32}$ Similarly, the increase in non-sexual violent films made it difficult to ascertain and isolate the impact of sexually violent films on crime statistics. Some, however, have argued that demographic trends largely explain the increase in US crime rates up until the mid-1990s and the subsequent reversal (Stephen \& Levitt, 2006).

Although all speech is entitled to First Amendment scrutiny, this does not prohibit its regulation (Pollard, 1990: p. 138). In particular, incitement to illegal activity and obscenity are exceptions that have been "carved out" by the Supreme Court (Pollard, 1990: pp. 138-139). The Court created a new exception for child pornography in Ferber but some scholars argue this was unnecessary, as objectionable child pornographic material already fell within the obscenity category (Pollard, 1990: p. 146). However, the Court chose not to continue this practice as it would risk some child pornography not being judged obscene (Pollard, 1990: p. 146). (Note: Ferber does not focus on the harm to society caused by the product but rather on the harm to children caused by the production process (Pollard, 1990: p. 147).

Although the Court's reasoning in Ferber at first appears strange and overbroad, ${ }^{33}$ it was the impracticality of then existing criminal law which compelled this result: when the criminal law is ineffective, the definition of the crime may need to be expanded (Pollard, 1990: p. 147). Thus, although a law might appear superfluous in theory, it was not in practice.

Professor Calvert has pointed out that adults have a First Amendment right to possess obscene material if it does not involve children. ${ }^{34}$ However, given the difficulty at times of distinguishing between obiter and ratio commentaries and the fairly recent creation of the child pornography exception, there is some dispute over this point. Other academics take the Osborne decision as revoking the right to possess both obscene and child pornography materials from First Amendment protections.

\footnotetext{
${ }^{29} 32$ F.3d 733 (3d Cir. 1994), cert denied, 513 U.S. 1109 (1995).

${ }^{30}$ Ibid., at 754 .

${ }^{31}$ Ibid., at 737 .

${ }^{32}$ Ibid., at 478 .

${ }^{33}$ It was overbroad in that, if the images portrayed a criminal act, it would be possible to prosecute the criminals involved in that act without criminalizing the viewers, purchasers or possessors of the images.

${ }^{34}$ In Stanley v. Georgia, 394 U.S. 557, 559 (1969) it was held that mere possession of obscene materials could not be criminalized. However, in Osborn v. Ohio, 495 U.S. 103, 111 (1990) it was held that possession of obscene child pornography was outside the First Amendment's protections.
} 
In the pre-1978 American conception, use of a minor in a pornographic production could not always be equated with abuse of a minor sexually. In fact, prior to 1977 , only one State had a statute specifically directed towards protecting children in pornographic media: the State of Tennessee (Payton, 1978-1979: p. 519). The statute, Tenn. Code Ann. S 39-3013 (1975), contained three notable innovations:

1) the law took an indirect approach to protecting children, and appears to have been written to protect children working in the industry as projectionists and sales clerks,

2) the law was directed at conduct rather than speech (as there was no sister legislation aimed at the product, child pornography),

3) the law specifically refers to "obscene" material despite being worded as protective of child conduct (rather than speech) (Payton, 1978-1979: p. 520).

In 1978 the Protection of Children Against Sexual Exploitation Act of 1977 was passed. Among other provisions, it extended the Mann Act's coverage to males (Payton, 1978-1979: p. 513). It also prohibited the photographing of children in sexually explicit activity and imposed penalties for shipping or receiving for the purpose of sale, or the selling, of such films or photographs (Payton, 1978-1979: p. 514).

The legislative history of the new law was complicated as it represented the cumulative wisdom of a negotiation involving sixteen related House bills and four Senate Bills (Payton, 1978-1979: p. 514). The most significant was Roth Bill S 1011 (Payton, 1978-1979: p. 514). Prior to the legislation's passing, the Justice Department made a number of objections, inter alia:

1) the bill did not distinguish between obscene material and that which was protected by the First Amendment,

2) that the definition of "prohibited sexual acts" also covered acts that were neither pornographic nor abusive of children,

3) that the term "lewd exhibition of the genitals" should be used in lieu of "nudity depicted for the purpose of sexual stimulation or gratification",

4) that there would be difficulties in regards to establishing the proof of age of the suspected child and,

5) that the penalties were excessive to the point of hindering prosecution (Payton, 1978-1979: p. 514).

In contrast, Kildee Amendment to H.R. 6693 followed a different rationale: it was directed at the abuse itself, rather than the obscenity, and held that those who distributed and sold child pornography were accessories after the fact to the crime of child abuse (Payton, 1978-1979: p. 515). It appears that this contrast in perceptions and goals is a theme which runs through much of the Supreme Court's jurisprudence on child pornography, perhaps undermining the coherence of later rulings or, at a minimum, offering two competing narratives: the victim-centered and the product-centered.

The Mathias-Culver Senate bill increased penalties for existing obscenity laws when the child models were under sixteen years of age (Payton, 1978-1979: p. 
516) while the Roth Amendment to the Mathias-Culver bill provided criminal penalties for knowing distribution of child pornography, regardless of whether such material was obscene or not (Payton, 1978-1979: p. 517). The Roth Amendment passed in the Senate 73-13, despite "every legal witness" at the relevant subcommittee having testified that it would not pass constitutional muster (Payton, 1978-1979: p. 517). Such was the state of the law, and perceived Supreme Court jurisprudence, in 1978.

By creating a new and separate category of child pornography, rather than subsuming it within the broader category of obscenity as had been done previously, the law would attempt to punish conduct through punishing speech. However, as neither child pornography nor child abuse were inherently federal concerns, the legislation needed to be drafted in terms relevant to federal powers e.g. interstate commerce or the mail (Payton, 1978-1979: p. 519).

\section{The Modern Era}

As the 1990s and 2000s witnessed the explosive growth in cyberspace, the problem of pornography, obscenity and child pornography fundamentally changed. Pornography became less visible in that it gradually disappeared from newsstands and convenience stores, while also becoming more prolific, specialized and diverse online. As women have become important consumers of pornography, public discussions over banning it have largely faded.

\subsection{Growth of the Internet}

It was concerns over the toxic mix of the Internet, anonymous users and online sexual predators targeting children which led to considerable fears and new legislation in the 1990s. Such legal responses were justified as media reports of children raped, bullied or blackmailed emerged, often as a result of contacts made through social media. In a sense, the increasingly stiff legal penalties often conflated three evils in one: the sexual predator, the act committed and the images created. Admittedly, all three were related, although some of the rationales, such as the Canadian court's concerns over allowing a "market" for images of brutalized children to develop, appear somewhat exaggerated in hindsight. In any case, such conflation between protecting children and criminalizing photos failed to anticipate technological progress or the nature of adolescent behavior.

In the 2010s, camera-equipped smart phones and social media became increasingly ubiquitous and a staple of teen life. No longer would teens who wished to send nude photos to each other require a web camera and a computer or other cumbersome equipment. The technological ease created new opportunities and temptations. Huge numbers of young people, in fact, millions of teenagers, began to share images of themselves and others (Madigan, Ly et al., 2018). ${ }^{35}$ It is simply an accident of history that the technology developed this way and the stiff anti-child pornography laws which had been passed earlier had failed to anticipate such behavior. And to the extent critics had warned about such possible developments, they had been largely ignored or ridiculed. 


\subsection{Child Pornography Formulations}

In the US, the federal statute on child pornography uses a definition which is different from that followed by the individual States. Most significantly, in the federal statute, simple nudity alone-as opposed to graphic or explicit nudity-would not be pornographic while States are free to set their own determinations. ${ }^{36}$

It is also important to bear in mind that child pornography laws are much more technical and reliable than obscenity laws as they rely more heavily on objective factors to determine whether the necessary thresholds have been met. While "community standards" may express vague notions often rooted in ideas of politeness or nuisance or morality, depictions of body parts or age of individuals at the time of portrayal offer some assurance of objectivity and predictability in court outcomes. In the case of simple possession of such material, the mens rea of the possessor may or may not be relevant depending upon how the statute is formulated. A strict liability approach would simply require that the photo have been taken at a time when the portrayed individual was below the threshold age (which is generally eighteen). A more defendant-friendly statute would require that the defendant actually believe or have reasonably believed that the individual portrayed had been below eighteen at the time the photo was taken. There are policy rationales for taking either approach. However, when society becomes sufficiently enraged by perceived injustices (e.g. rape or child pornography) it will often demand that the legal formulation be tweaked so as to achieve a greater number of criminal convictions. ${ }^{37}$

\subsection{Teen Pornographers}

In the American context, an important distinction emerges between extreme child pornography (e.g. involving exploitation, depictions of young children, or rape) and the ordinary child pornography produced by teens below eighteen years of age on a voluntary basis (generally for the benefit of other teens or their typically near-age partners). Since the term "child pornography" can be applied ${ }^{35}$ The exact number of under eighteens who have taken a nude picture or sex video of themselves is unknown. It seems that this behavior increases with age (e.g. a seventeen-year-old will be more likely to have done so than a thirteen-year-old). The extent to which such images are shared physically or forwarded electronically is also unknown. Even less known is how many successfully delete these photos before turning eighteen.

${ }^{36}$ Under the federal criminal law definition, material would be child pornography if it involved a minor in either 1) one of several specified sexual acts or 2) the "lascivious exhibition of the genitals or pubic area". With regards to the first branch of the definition, 18 U.S.C. $\$ 2251,2256(2)$ (A) (i-iv) (2006) prohibits either actual or simulated "sexual intercourse, including genital-genital, oral-genital anal-genital, or oral-anal, whether between persons of the same or opposite sex" as well as masturbation, bestiality and sadistic or masochistic abuse. With regards to the second branch, see 18 U.S.C. $\$ 2256(2)(\mathrm{A})(\mathrm{v})$.

${ }^{37}$ Changing the definition of a crime is one way to achieve more convictions. Increased efforts at evidence gathering or witness protection might be another. Recently, the British government has stepped up its effort to secure a higher number of rape convictions, although numerical targets for prosecutions or conviction rates might be problematic for those who adhere strictly to the "justice should be blind" mindset. See https://www.gov.uk/government/news/response-to-rape-overhauled (Accessed January 15, 2022.) 
to both, and the evil to be prevented is often identified as being at least partly located within the photo itself rather simply than the relationship between the viewer and the photo, the law will consider both types of photos to be contraband. Only recently has the law begun to decriminalize the latter category and often only for a short period of time (e.g. until the image possessor turns twenty). ${ }^{38}$ Yet it is often impossible for third parties to know the age of the person portrayed at the time the photo was taken. There is also no consensus as a society on how the law should treat such photos over the long term.

\subsection{Sexting in Schools}

The term "sexting" is a portmanteau of "sex" and "text", used to describe the phenomenon of sending sexually charged messages or images over the internet, increasingly through cell phones. It is a phenomenon which is not limited to young people, as Amazon CEO Jeff Bezos's marriage famously ended after he was discovered to have sexted his mistress. ${ }^{39}$ In general, however, sexting appears to be largely a teenager and young adult phenomenon.

For analytical purposes, the sexting which occurs among students may be classified as either consensual or non-consensual. For example, if a female student sends a nude self-photograph ("nude selfie") to her boyfriend or prospective partner, this will typically be construed legally as a consensual act (even if done under pressure). However, if the boy later sends the same photo to another person, this may be considered non-consensual from the perspective of the girl portrayed. In most cases there will now be a "revenge pornography" statute at the State level, either as a matter of criminal or tort law, to limit the risk of such an act. However, if no such law exists, there may still be a common law tort remedy or, if she was below eighteen years of age at the time of portrayal, at least a child pornography law to protect her rights. (As explained above, the child pornography provisions may be problematic from the perspective of third parties who are unaware of her age at the time of portrayal.)

The non-consensual pornography is often referred to as "revenge pornography" and this description is accurate in typical cases. However, "revenge" implies a relationship between the image distributor and the victim which may not always exist. In some cases, the image distributor will be a third party e.g. a love rival who finds the images on her boyfriend's phone. The motive of the love rival might be jealousy or amusement rather than actual vengeance for a wrong inflicted.

${ }^{38}$ Ryan E Little, Teen "sexting” would be decriminalized with Maryland Bills, Capital News Service, February 10, 2020. https://www.delmarvanow.com/story/news/local/maryland/2020/02/10/teen-sexting-would-decrimi nalized-maryland-bills/4693681002/ (Accessed Jan 15, 2022.) States are continually updating their laws and a good interactive source for reasonably up to date information is https://cyberbullying.org/sexting-laws (Accessed January 15, 2022.)

${ }^{39}$ Team Latestly, Jeff Bezos' Lewd Sexting \& X-Rated Dick Pics Sent to Lauren Sanchez Surfaces-The Reason Behind Amazon CEO's Divorce with Wife MacKenzie Bezos, January 11, 2019 https://www.latestly.com/lifestyle/jeff-bezos-lewd-sexting-x-rated-dick-pics-sent-to-lauren-sanchezsurfaces-the-reason-behind-amazon-ceos-divorce-with-wife-mackenzie-bezos-584509.html (Accessed January 15, 2022.) 
Where sexting occurs on campus or within the classroom, school officials will often be within their authority to seize the student's phone and/or discipline the student (i.e. subject to whatever rules exist at the State level). However, where the activity takes place outside school hours and off campus, the powers of school officials to seize phones will be more constrained. For example, it may be difficult to assert an imminent breach of the peace or disruption of classroom activities would occur if sexting happens on a Saturday night or over the winter holidays. For officials seeking to discipline the students, the test employed at the State level will often be one related to the threat of classroom disruption. Under both the First and Fourth Amendments, students, even if minors, are entitled to both free speech and privacy rights. Therefore, teachers and school officials need to exercise care in their approach.

These sexually explicit texts, often accompanied by sexually explicit photos of themselves, may be solicited or unsolicited. The tendency to send unsolicited sexually explicit images appears to be stronger among males than females. If repeated, this behavior could be construed as harassment or sexual harassment. ${ }^{40}$ If this behavior occurs after hours, away from school grounds, involvement of school officials may be minimized and, if alerted, school officials may simply inform the police and allow the normal criminal justice system to handle this. Several lawsuits have been brought against schools and education boards alleging negligence in failing to protect students from the harm of bullying. The Court's view has been that, in order to defeat a governmental claim for immunity (e.g. as applied to a publicly-funded school), the plaintiff must establish the presence of: 1) an identifiable victim, 2) an imminent harm, and 3) a public official to whom it was apparent the conduct was likely to subject the victim to harm (Conn, 2011: pp. 237-238). Traditionally, satisfying all three limbs has been a high hurdle to meet.

If the offensive behavior occurs during school hours or is sufficiently disruptive as to prevent normal class activity from occurring, or creates an unsafe environment, teachers may be within their rights to seize phones or expel students etc. (Willard, 2011: p. 76). ${ }^{41}$ However, as a practical matter, it appears that the threshold for teacher involvement will be higher when the activity occurs outside school hours and away from the school (Willard, 2011: p. 77). On the other hand, if the disruptive behavior (e.g. sexting or forwarding revenge pornography) occurs through the District Internet system or through digital personal de-

\footnotetext{
${ }^{40}$ It appears that in the early Internet days, lawsuits claiming school liability for bullying were framed as Title IX peer sexual harassment claims. Under Title IX, universities may be held responsible if they do not properly recognize or address incidents of campus sexual assault and harassment. See Kathleen Conn, "Bullying in K-12 Public Schools: Searching for Solutions," Commonwealth Educ. Pol'y Inst., 4 (2006),

http://www.cepi.vcu.edu/pdf/Policy\%20Briefs/Kathleen\%20Conn-Bullying\%20VCU\%20PolicyPaper \%202-11-06.pdf. (Accessed January 15, 2022.)

41 "The disruption must be likely to impact students and interfere, or potentially interfere, with their right to be safe at school and receive an education". Nancy Willard, "School Response to Cyberbullying and Sexting: The Legal Challenges," Brigham Young University Education and Law Journal, Spring, No. 1, Art 5 (2011): 75-125 at 76.
} 
vices used at school for pedagogical reasons, then school officials may act (Willard, 2011: p. 77).

It is worth noting that online bullying takes one of two forms: through known and unknown tormentors. Generally, it is done through social media e.g. on Facebook or Twitter accounts in which the victim is a participant. (If the target of the harassment were not a member of the site, she might be blissfully unaware of the hateful comments and views. There are also websites devoted solely to gossip and criticism of others such as www.thedirty.com, although these tend to be only special interest sites, often geared more towards adults.) The harassment that occurs on social media may be done by individuals identifiable to the target or through "fake profiles" i.e. individuals who hide behind photos of others or spoof accounts, thus of unknown identity to the harassment target. Teens and younger generation individuals seem to be more vulnerable to criticism or ostracism and more likely to commit suicide or suffer mental illness as a result. In response, some States, such as North Carolina, have made it a crime to create a fake profile or website with the intent of tormenting a child. ${ }^{42}$

\subsection{Cell Phone Searches on Campus}

In order to search a student's cell phone or personal computer, the teacher or school official must have a reasonable suspicion that the search is likely to reveal a law or school policy has been violated (Willard, 2011: p. 77). ${ }^{43}$ Again, this will likely not be a difficult threshold to reach when the issue is a serious matter such as student-generated pornography. However, the line between pornographic and non-pornographic photography will vary from State to State and school officials will likely not always be familiar with the local law. In fact, prosecutors have at times made missteps. ${ }^{44}$

A further complication, as mentioned above, is that the original date of recording of the photos may be uncertain. Thus, an eighteen-year-old student may be in possession of a photo from a year earlier, which would therefore qualify as child pornography. School officials must not delete such photos as such photos may be evidence of a crime (and deletion could invite a charge of evidence-tampering). However, school officials must not retain such photos as to do so could lead to charges of possession of child pornography. ${ }^{45}$ The school of-

${ }^{42}$ N. C. GEN. STAT. ANN. $\$ 14-458.1$

${ }^{43}$ Nancy Willard, Supra note 92, at 77.

${ }^{44}$ In Pennsylvania, an ambitious prosecutor attempted to include the photo of a seventeen-year-old girl in an opaque bra in his "child pornography" submission. See Miller v. Mitchell, 598 F.3d at 144 In fairness to the prosecutor, for cultural reasons, a photo of an individual wearing an opaque bra may be more easily construed as a sexual pose whereas a photo sporting a bikini top might not be.

${ }^{45}$ Kim Zetter, "Sexting" Hysteria Falsely Brands Educator as Child Pornographer, Wired Magazine (Apr. 3, 2009), http://www.wired.com/threatlevel/2009/04/sexting-hysteri/. (Accessed January 15, 2022.) The school officials should also be wary of over-sharing such images to other administrators not directly involved in the investigation, lest they be charged with distributing child pornography. See Joel Elias \& Daniel Victor, Susquenita High School Officials Being Investigated for Handling or Images in "Sexting" Case, The Patriot News (Apr. 15, 2010, 12:00 am),

http://pennlive.com/midstate/index.ssf/2010/04/susquenita high school officia.html.

(Accessed January 15, 2022.) 
ficials are also advised not to return the photos (camera phone etc.) to the student lest the student delete the said photos (given the school officials' duty to preserve evidence) (Willard, 2011: p. 124).

From the vantage point of criminal law, the safest course appears to be for school officials to immediately contact law enforcement even though, if the photos in question are not child pornography, the school officials will be interfering with the student's rights and, by escalating things in this manner, may have even be aggravating the risk of a student-initiated lawsuit (Willard, 2011: p. 111). ${ }^{46}$ For example, in New Jersey v. T.L.O, ${ }^{47}$ the US Supreme Court stated that the Fourth Amendment prohibition on unreasonable searches and seizures extends to searches of students and their possessions by public school officials. ${ }^{48}$

Such searches must be reasonable and related to the school's need to maintain order. ${ }^{49}$ To justify the search, there must be reasonable grounds for suspecting that it will discover evidence that the student has violated or is violating either school policy or the law. ${ }^{50}$

It is unclear if law enforcement officials stationed on campus operate under the same or different rules as those which apply to school officials (Willard, 2011). If nothing else, as a matter of practice, a student may be less willing to assert his right to refuse a request for a search of his phone if the request is made by a police officer (Willard, 2011: pp. 120-121).

Of course, failure by school officials to investigate a potential wrongdoing is not a real option. In the case of Jessica Logan, her ex-boyfriend shared the nudes that she herself had sent him (Kimball Perry, 2009). This led to bullying of Miss Logan, particularly by her fellow female students ${ }^{51}$ and, eventually, to her suicide (Kimball Perry, 2009). Her parents subsequently sued the school district and the local police force for not having done enough to prevent the harassment. (Kimball Perry, 2009) The worst offending students were also sued, although a settlement was reached (Conn, 2011: p. 244).

With regards to camera phones on campus, the school may have a policy to ban their presence or ban their use. However, this alone would only justify the confiscation of phones by school officials (Willard, 2011: p. 121). It would not justify a search of the phone itself..$^{52}$ Additional and related suspicion of wrongdoing would be necessary (Willard, 2011: p. 121).

In Saxe v. State College Area School District, ${ }^{53}$ the school district's an-

${ }^{46}$ For example, the student might claim his First and Fourth Amendment rights were interfered with. Some scholars even go so far as to suggest, if no crime is committed on campus, the school may not be justified in taking a disciplinary response. See Nancy Willard, Supra note 92, at 111.

${ }^{47}$ New Jersey v. T.L.O, 469 U.S. 325 (1985).

${ }^{48}$ New Jersey v. T.L.O, 469 U.S. 325, 333 (1985).

${ }^{49}$ New Jersey v. T.L.O, 469 U.S. 325, 326 (1985).

${ }^{5}$ OIbid.

${ }^{51}$ In addition to calling her "slut" and "whore", the girls threw objects at her. Melissa Thomas, "Teen Hangs Herself After Harassment For a 'Sexting' Message, Parents Say”, Courthouse News Service (Dec. 7, 2009),

http://www.courthousenews.com/2009/12/17/Teen_Hangs_Herself_After_Harassment_For_a_Sexti ng Message Parents Say.htm. (Accessed January 15, 2022.)

${ }^{52}$ Klump v. Nazareth Area School District, 425 F. Supp. 2d 622, 640 (E.D. Pa. 2006). 
ti-harassment policy was challenged as being overbroad, that it might restrict speech that was merely offensive. Judge Alito (as he then was) noted that in order to constitute harassment under the "hostile environment" theory, two conditions must be met: 1) the speech must be viewed subjectively as harassment by the victim and 2) it must be objectively viewed as sufficiently severe or pervasive that a reasonable person would agree it was harassment. ${ }^{54}$ Thus, for the student targeted by revenge pornography or unsolicited "dick pics" etc. the dual standard would apply: 1) subjectively she must view herself as harassed and 2) the behavior must be objectively viewed by a third party as harassment. While such extreme examples might be rather clear-cut cases of harassment, it is harder to predict how courts would react to borderline cases e.g. racially offensive photos or merely sexually suggestive and innuendo photos (such as an African-American eating a chicken or a photo of a hotdog in a bun). Despite this case law, and the clear need to protect students from harassment, the American Civil Liberties Union (ACLU) has taken the position that school authorities have no authority to respond to speech that takes place off campus (Willard, 2011: p. 95).

\subsection{Attempts to Control Sexting among Students}

The Court's distinction between on and off campus activities appears increasingly tenuous given the growth in social media and 24-hour Internet access. Students may post at the campus gate, prior to entering the school. Or students may read the earlier postings of others during class breaks. Thus, the off-campus postings may lead to on-campus altercations (Willard, 2011: p. 104).

In the case of J.C. v. Beverly Hills United School District, ${ }^{55}$ J.C. created a Youtube video in which many students disparaged fellow C.C. ${ }^{56}$ Although J.C. was suspended, the Court found a lack of due process as, at that time, neither State statute nor district policy provided any notice of a policy regarding off-campus speech. ${ }^{57}$

In the US case of Tinker $v$ Des Moines Independent Community School District ${ }^{58}$ the Supreme Court held that the free speech rights of public high school students may be abridged if the public authorities have reason to believe that there will be a disruption of material interference with school activities or when the speech materially disrupts classwork or the rights of others. ${ }^{59}$

Displaying a nude image of another student during school hours would clearly be disruptive (Calvert, 2009: p. 36). However, the question remains, would such activity be punishable if done in the evening, on the weekend or between school terms? Certainly, if the school can punish a student for making a speech full of

\footnotetext{
${ }^{53}$ Saxe v. State College Area School District, 240 F.3d 200, 204 (3 $3^{\text {rd }}$ Cir. 2001).

${ }^{54}$ Saxe v. State College Area School District, 240 F.3d 200, 205 ( ${ }^{\text {rd }}$ Cir. 2001).

${ }^{55}$ J.C. v. Beverly Hills United School District, 711 F. Supp. 2d 1094 (C.D. Cal. 2010).

${ }^{56}$ Ibid., at 1098.

${ }^{57}$ J.C. v. Beverly Hills United School District, 711 F. Supp. 2d 1094, 1098, 1102 (C.D. Cal. 2010).

${ }^{58} 393$ U.S. 503 (1969).

${ }^{59}$ Ibid., at 513.
} 
sexual innuendoes (see Bethel School District No. 403 v. Fraser ${ }^{60}$ ) then it should be able to also punish for the more extreme act of displaying a sexually explicit image (Calvert, 2009: p. 37). And while the trend is towards courts allowing school officials to punish students for speech made off campus (Calvert, 2009: p. 37), a major problem often still dominates: in high school, the students are generally minors. And minors under 16 have both a duty and a right to attend school. Moreover, a school realistically has power only over students who wish to maintain positive relations with the school e.g. the academically ambitious. There is little a school can do to blacklist or control a student who has already graduated, transferred or dropped out.

At the State level, lawmakers are increasingly giving school officials the tools to combat cyberbullying, including expulsion (Calvert, 2009: pp. 38-39). Of course, student-led remedies such as a civil lawsuit over intentional infliction of emotional distress remain a possibility. For this tort there are four elements which the Claimant must prove:

1) Intentional or reckless conduct by the Defendant

2) Extreme and outrageous conduct by the Defendant

3) A causal connection between the conduct and the distress suffered and

4) The emotional distress was severe (Calvert, 2009: p. 41).

The Restatement (Second) of Torts ${ }^{61}$ states that this liability does not extend to mere insults or other trivialities. ${ }^{62}$ However, for those who are traumatized by publication of their nude photos, it should not be difficult to prove that distribution of a nude photo or pornographic video etc. would be distressful or outrageous conduct. The difficult factual issue, however, may be establishing the nexus between the emotional harm and the Defendant's conduct. This is because many Defendants will claim no knowledge as to how the photo or video came to be publicized.

\subsection{Images Stored on the Cloud}

On August 31, 2014 a large number of private photos of young celebrities, many being nude "selfies", were posted on the imageboard 4chan.org. In total, nearly 500 photos were posted, including intimate photos of top celebrities such as Kate Upton, Jennifer Lawrence and Arianna Grande.$^{63}$ These photos had been taken

${ }^{60} 478$ U.S. at 684 .

${ }^{61} \$ 46(1965)$.

${ }^{62} \$ 46 \mathrm{cmt}$. d (1965).

${ }^{63}$ It should be noted, however, that Ariana Grande initially denied that these were actual photos, implying that photoshop technology had been used. She and McKayla Maroney later claimed that the photos were authentic yet had been taken before they turned eighteen, perhaps in an effort to compel possessors to delete them, while paradoxically asserting copyright over them. See Billboard Staff, “Ariana Grande Denies Authenticity of Alleged Leaked Nude Photos”, 8/31/2014. https://www.billboard.com/articles/news/6236536/ariana-grande-denies-authenticity-of-alleged-leak ed-nude-photos, (Accessed January 15, 2022.) See also Gil Kaufman, “Gymnast McKayla Maroney Says She's Underage in Hacked Photos”, mtv.com, 09/03/2014. https://www.mtv.com/news/1919057/gymnast-mckayla-maroney-underage-hacked-photos-liz-lee/. (Accessed January 15, 2022.) 
from the Cloud, in many cases after the young actresses had deleted the pictures on their own Apple iPhones, often unaware that despite deleting from one's phone, the default setting was for backup copies to remain stored in the iCloud. ${ }^{64}$ Initially, speculation in the press suggested that a "brute force" type of hacking ${ }^{65}$ had occurred or perhaps even an Apple insider might have been involved. ${ }^{66}$ However, the general consensus now suggests that most if not all of the photos publicized around that time had been accessed either through "phishing" and/or rather simple hacking techniques based on readily available information about the celebrities. ${ }^{67}$ For example, the names of a celebrity's dogs or birthdays of family members can often be easily ascertained through Google searches or from Wikipedia pages. Where the high school students know each other's information well e.g. birthdays or pet names etc., it may be relatively easy to guess passwords or even physically access the "secret" folders on a phone or social media site.

\subsection{Decriminalization: The Road to Nowhere}

If it can be said that American politicians are increasingly reactive and failing to anticipate the problems their laws are creating, it must be acknowledged that a large part of the problem lies in the education of the populace. And the failure to educate is really a failure of the teachers.

${ }^{64}$ James Cook, Celebrities Victimized in the iCloud Naked Photo Hack Want to Sue Google for \$100 Million, Bus Insider, (Oct 2, 2014), http://read.bilr19OGM. (Accessed January 15, 20212.) See also, Adam Clark Estes, What is the "Cloud"-And Where Is It?, Gizmodo (Jan. 29, 2015), http://bit.ly/lpKCnfs the term "cloud" vaguely suggests a superior location or set of locations where the data cannot be destroyed, yet will still be accessible from anywhere. (Accessed January 15, 2022.) ${ }^{65}$ See

https://www.ibtimes.co.uk/icloud-accounts-risk-brute-force-attack-hacker-exploits-painfully-obviou s-password-flaw-1481623. (Accessed January 15, 2022.)

${ }^{66}$ See Jacob Kastrenakes, "Apple denies iCloud breach in celebrity nude photo hack”, The Verge, Sept $2,2014$.

https://www.theverge.com/2014/9/2/6098107/apple-denies-icloud-breach-celebrity-nude-photo-hack. (Accessed January 15, 2022.) I discussed this theory with several Apple engineers working at the firm's Japanese headquarters in Tokyo in 2014-2016. They assured me it was virtually impossible for such a scenario to play out as the firm's internal firewalls were extremely high. Only a very limited number of Apple employees would ever be able to access such photos. On the other hand, Apple more recently announced plans to create an internal check within the iPhone, independent of the cloud itself, which would search iPhones for child pornography, against a database of known child pornography images (CSAM image hashes provided by NCMEC (the National Center for Missing and Exploited Children) and other child safety organizations). However, in the face of hostile publicity from privacy advocates, Apple has, at least temporarily, abandoned this plan. Most customers likely have no interest in child pornography, although it is unclear how many would wish to have Apple examining their "private" photos even before uploading them to the Cloud. See Tyler Durden, “'This Is About Control, Not Children': Eric Weinstein Calls Out Apple's Virtuous Pedo-Hunter Act”, ZeroHedge.com, August 8, 2021.

https://www.zerohedge.com/technology/about-control-not-children-eric-weinstein-calls-out-applesvirtuous-pedo-hunter-act. (Accessed January 15, 2022.)

${ }^{67}$ It is unclear how many of the photos were obtained through phishing and how many were obtained from successful password speculations. At various times, the mainstream media has put forward competing individuals as "the culprit" behind Celebgate yet it is also possible that more than one individual obtained the same photos and more than one technique was involved. See "Meet the man behind the leak of celebrity nude photos, called the fappening", BBC News, 16 March, 2016. https://www.bbc.com/news/newsbeat-35820521. (Accessed January 15, 2022.) 
As media focus on problems such as the Jessica Logan suicide brought to light a moral failing within America (by all parties concerned), it is important to keep some elements (e.g. revenge pornography and other forms of bullying) analytically distinct from the issue of child pornography.

Clearly, social media is problematic and largely exploitative, as children are intellectually and emotionally less developed than adults. As a consequence, the law is moving in the direction of protecting children from bullying. Yet the problem of possession of child pornography is complicated, partly by the fact that boys are often less mature than girls.

As things stand, the intended beneficiaries of the child pornography laws are often now committing crimes, reliant upon the goodwill and common sense of prosecutors to not bring charges against them. However, in general, many of these children will become de facto criminals living in a weaker and weaker legal position over time, at least for as long as they continue to possess those images. For example, public opinion may tolerate an 18-year old man with a memorial nude photo of his former girlfriend, taken when they were both 16. Public opinion, and most likely the law as well, will grow less tolerant as he ages, particularly if he does not marry that girl. The law in practice often does not live up to the law in theory.

There are no easy solutions to this problem as even setting a higher cut-off age (e.g. twenty-five) really amounts to little more than the further infantilization of young adults. And the problem which hits at eighteen (i.e. an adult possessing child pornography) would simply be delayed until he reached twenty-five.

Perhaps it is unfair to apply so much logic to the law. Certainly, it is easier to criticize law than to create it. Yet the underlying intellectual confusion at the root of child pornography law becomes clear when one examines its manifestation: does the "evil" to be controlled lie in the photo itself, the process of creating it or the relationship between the photo and the viewer? For those operating from a more traditional framework, evil can only exist in the mind of an individual. Thus, mere possessing or viewing etc. cannot make one evil: if it did, the police and the prosecution service would also become evil. Something more is needed.

This trivial point is mentioned because the decriminalization path for teenagers that is increasingly being adopted by the States has two problems: 1) it merely "punts the ball" and attempts to delay criminalization and/or the discussion of criminalization and 2) it fails to address the important issue of the relationship between the image and its possessor.

\subsection{Image Possessor}

The key problem with misidentifying the evil of child pornography as being within the photo itself, rather than in the relationship between its possessor and the image is that all of the following possessors would, sooner or later, become criminals:

1) a seventeen-year-old who takes a nude selfie but grows up before deleting it 
2) her boyfriend who was also given this photo but who keeps forgetting to delete it

3) the man she met on a Tinder date in her twenties and used it to entice

4) her ex-boyfriend's friend who somehow got hold of it

5) a middle-aged pervert who knows how to hack computers

While it may be obvious that the latter case(s) deserve to be criminalized, it is sometimes unclear what legal test should be applied or where the crime lies. In the last case, for example, at least three types of wrongdoing present themselves: 1) intrusion upon seclusion, 2) the hacking/theft of the photo and 3) the possession of child pornography. However, a legal purist might argue that child pornography charges should not be applied if there was no mens rea to look at or possess such photos. While the first two wrongdoings are fairly straightforward, the third presents a rather fine legal point: thieves do not always know precisely what they are stealing.

If common sense is applied, and there is no underlying crime (e.g. a nude teenager looking at herself in a mirror or having sexual relations with a boy of her own age) then why should a photo of these activities be criminalized? And, if an exception is made for case 1), should it also be extended to case 2)? The point here is not to legitimize nefarious behavior but simply to illustrate the difficulty in drawing the line.

Although there are no easy answers to these sorts of questions, one thing is clear: the fewer the number of exceptions which are allowed, the greater the number of criminals which will ensue.

\section{Recommendation}

There are no easy solutions to the problems presented in this paper. However, at a minimum, it is suggested that in the case of uncoerced self-produced pornography with a single visible participant, no criminal sanction should be levelled or exist against the creator simply on the basis of possession of such an image. Particularly where the photo is made in her late teens, she alone might know what her age had been at the time of its creation. If the photo had been taken before she was eighteen and she chooses to publish or distribute it, it might be reasonable to bring charges against her for distribution of child pornography. But for the state to bring possession-related charges against her, simply on the basis that it discovered she was holding onto a childhood memento or had been using it to compare her current and former appearance, seems a bridge too far.

The case for a boyfriend or love-interest who was given such photos is more difficult to make. The law's presumption of wrongdoing in respect to creation, distribution and possession may seem reasonable if one assumes that only bad people are interested in such things. On the other hand, there may be a distinction between a boyfriend holding such images and a stranger holding such images. The problem most often arises when the boyfriend becomes an ex-boyfriend.

As the law currently stands, the boyfriend/ex-boyfriend would be at risk of revenge pornography charges if he distributed the image (regardless of the age 
portrayed in the photo) while he would also be at further risk of child pornography charges if he possesses or distributes a photo taken prior to the portrayed party's having turned eighteen. In reforming (or not reforming) the law, key questions that need to be considered include:

1) Should the age of the individual portrayed be part of the mens rea or the actus reus of the crime?

2) Should there be a "possession exception" that allows for a distinction to be made between commercial pornography and love interest photos (i.e. images voluntarily shared or shared without consideration)?

3) Is it even reasonable to discuss assigning agency to older teens (e.g. sixteen and seventeen-year-olds) or would such a policy of moving goal posts simply open the door to abuse of younger teens?

On balance, it may be that hard cases make for good laws. The popular male practice of holding onto such images, even after having been asked to delete them, is a good argument for keeping the law as it is. The risk the boys will not delete may encourage the girls not to share such images. And the risk of child pornography charges may induce the boys to not distribute or even hold onto the images. Insofar as the explanation given to young people is deceptive, however, it is unlikely that such a policy will prove sustainable in the long run.

\section{Conclusion}

For the liberal, writing a paper on pornography fifty years ago would surely have been more fun. The legal difficulties in distinguishing between erotica and pornography could have been explored or the contradictions created by social convention and fuddy-duddy conservatives might have been exposed. Alan Dershowitz, for example, pushed the narrative that pornography was a free speech and not a women's rights issue, and that community standards as a legal test might be problematic if a local prosecutor came to set national standards. ${ }^{68} \mathrm{We}$ now live in the aftermath of the liberal's legal victories.

The problem of pornography is fundamental to a paradox, or perhaps even a contradiction, within the American story. Originally written largely by Puritans, who bore both a rather narrow worldview on moral issues yet also sought political and religious freedom, the US Constitution and its jurisprudence have in many ways shaped international law without wishing to be shaped by it. Yet, as the demographics of the nation have changed and internationalized, so too have the belief systems of the citizenry. And the Constitutional document has now been reinterpreted by people with arguably very different values from the originators. For example, not only is the current US Supreme Court overwhelmingly dominated by Roman Catholics and ethnic Jewish people, but it appears that other industries, such as Hollywood and the pornography industry, may be similarly unrepresentative of traditional America as well. ${ }^{69}$

${ }^{68}$ The root of the problem was the Court's (deliberate?) use of ambiguous language with respect to "community". Alan Dershowitz noted at the time, "If a local prosecutor doesn't like a magazine or film, he can set himself up as a national censor." NEWSWEEK, Feb. 21, 1977, at 34, col.2. 
Insofar as demographics determines destiny, and public policy sits downstream from culture and education, the law will need to change with the times. Yet it was clearly a great mistake to succumb to the liberal demand and attempt to divorce the law from morality, creating a society where everyone wants to understand the law but no one knows what is right or wrong. This public morality/private morality distinction has only proven sustainable in theory, never in practice.

To have good laws, the law needs to reflect reality, not ideological preconceptions or sensationalist media narratives. The post WWII trend of both liberalizing pornography and later tightening controls over child pornography is difficult to argue against. Yet, it is increasingly evident that the law in many ways is no longer fit for purpose, having assigned to legal children the role of victim, and failing to allow older children a scope for agency or autonomy, even after they become adults. The law needs to be reformed. The unfortunate reality, however, is that it will remain difficult to do so, at least while people like Prince Andrew are waiting in the wings.

\section{Conflicts of Interest}

The author declares no conflicts of interest regarding the publication of this paper.

\section{References}

Bradley, G. V. (2018). Prolegomenon on Pornography. Harvard Journal of Law \& Public Policy, 41, 447-498.

Calvert, C. (2009). Sex, Cell Phones, Privacy, and the First Amendment: When Children Become Child Pornographers and the Lolita Effect Undermines the Law. CommLaw Conspectus: Journal of Communications Law and Policy, 18, 1-66.

Clough, J. (2012). Lawful Acts, Unlawful Images: The Problematic Definition of Child Pornography. Monash University Law Review, 38, 213-245.

Conn, K. (2011). Allegations of School District Liability for Bullying, Cyberbullying, and Teen Suicides after Sexting: Are New Legal Standards Emerging in the Courts? New England Journal on Criminal and Civil Confinement, 37, 227-246.

Dubner, S. J., \& Levitt, S. (2006). Freakonomics (Chapter 4). Harper Trophy.

Madigan, S., Ly, A., Rush, C. L., Van Ouystel, J., \& Temple, J. R. (2018). Prevalence of Multiple Forms of Sexting Behavior among Youth: A Systematic Review and Meta-Analysis. JAMA Pediatrics, 172, 327-335. https://doi.org/10.1001/jamapediatrics.2017.5314

Mather, V. M. (1992). No Harm, No Foul: Pornography (Violent and Otherwise). University of Arkansas at Little Rock Law Journal, 14, 445-490.

\footnotetext{
${ }^{69}$ With regard to current makeup of the Court, only Justice Gorsuch may lay claim to being a Protestant. However, even there the claim is tenuous at best, as he was raised a Roman Catholic and may be simply following the tradition of adopting the wife's religion for convenience (i.e. the sake of the children). It is unclear whether or not he has converted and, in any case, the family attends a liberai Episcopalian church. See Daniel Burke, "What is Neil Gorsuch's religion? It's complicated", CNN Politics, March 22, 2017.

https://edition.cnn.com/2017/03/18/politics/neil-gorsuch-religion/index.html (Accessed January 15, 2022.)
} 
Ortiz, F. (2001). Zoning the Voyeur Dorm: Regulating Home-Based Voyeur Web Sites through Land Use Laws. U.C Davis Law Review, 34, 929-1004.

Payton, J. M. (1978-1979). Child Pornography Legislation. Journal of Family Law, 17, 505-544.

Perry, K. (2009, May 12). Lawsuit Filed Over "Sexting” Suicide. Cincinnati.com. http://news.cincinnati.com/article/20090512/news0107/305120011/lawsuit-filed-over-s exting-suicide

Pollard, D. (1990). Regulating Violent Pornography. Vanderbilt Law Review, 43, 125-160.

Willard, N. (2011). School Response to Cyberbullying and Sexting: The Legal Challenges. Brigham Young University Education and Law Journal, 2011, 75-125. 